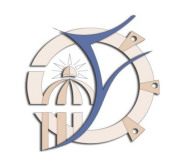

Fayoum University
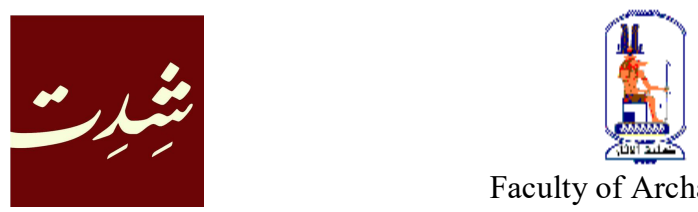

Faculty of Archaeology

\title{
ANGELS IN COPTIC TRADITION
}

\section{Ibrahim SAWEROS}

\author{
Lecturer of Coptology, Faculty of Archaeology, Sohag University \\ E-mail: i.saweros@gmail.com
}

\begin{abstract}
This article begins with a general overview of Coptic Angelology. I give special attention to the accompanying angel, the angels of the altar and then to the archangels Michael and Gabriel. The tasks of the angelic figures were studied in detail. I also use some recently edited Sahidic homilies attributed to St. Athanasius of Alexandria (ca. 296/298-2 May 373), together with many Coptic literary works to shed more light on angels and their role in Coptic tradition.
\end{abstract}

الملخص

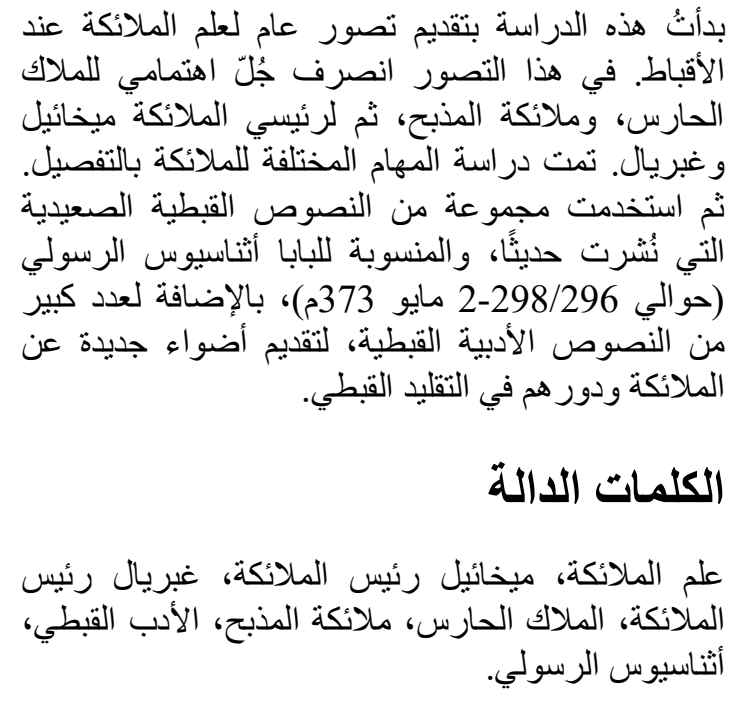

\section{KEYWORDS}

Angelology, Michael the Archangel, Gabriel the Archangel, The Accompanying Angel, Angels of the Altar, Coptic Literature, Athanasius of Alexandria.

\section{INTRODUCTION}

Sketching even the barest outline of the rich Coptic angelology and its Biblical and apocryphal roots is a task that by far surpasses the scope of the present article. Since angels, and in particular Michael and Gabriel, play an important role in the homilies edited in my $\mathrm{PhD}$ dissertation, ${ }^{1}$ in the following pages I will try to give an idea of some aspects of angelic presence in the Coptic tradition. I start from general concepts and then go on specifically to examine how the Christian literature of Egypt presents Michael and Gabriel.

\footnotetext{
${ }^{1}$ Saweros, Another Athanasius: Four Sahidic Homilies attributed to St. Athanasius of Alexandria. This dissertation was supervised by Prof. Dr. Jacques van der Vliet (Leiden University), to whom I would like to express my deep gratitude. The core of the dissertation will appear soon in two volumes by Peeters Publishers (Belgium). The four Athanasian works which were edited and translated in the dissertation, and which are quoted quoted in this article, are an encomium on Michael and Gabriel the Archangels (CPG 2197, Clavis Coptica 0059), a homily on Greed and Murder and on Michael the Archangel (CPG 2191, Clavis Coptica 0048), a homily on Luke 11, 5-9 (CPG 2194, Clavis Coptica 0057), and a homily on Pentecost (CPG 2191, Clavis Coptica 2191).
}

- 74 - SHEDET Issue nu. 6 (2019), pp. 74-91 
As our texts were mostly produced and transmitted in a monastic milieu, I mostly quote monastic sources. Throughout this article, I am seeking answers for three main questions, about the nature, job and rank of the angels. ${ }^{1}$ In so doing, I am mainly using the four texts I edited on Coptic angelology. I should make clear that the most important study on Coptic angelology appeared six decades ago. ${ }^{2}$ Although mostly descriptive in nature, Müller's study is a seminal work. However, since its appearance, many Coptic literary works have been edited, thus new analytical studies are needed.

\section{THE ACCOMPANYING ANGEL}

Generally, angels are a very common subject in the Christian literature of Egypt. Angels appear as unseen, powerful creatures that accompany the righteous ones during their life and at the time of their death until they enter the kingdom of God. In a famous passage from the Arabic Life of Shenoute, known as The First (Arabic) Apocalypse of Shenoute, ${ }^{3}$ the unknown author relates that the angels will rejoice with the holy ones who will survive the torture of the final days. The angels will invest them with the garments of glory which they will wear throughout their endless time in the kingdom of God. ${ }^{4}$

Shenoute himself (d. 465) used the theme of angels frequently in his writings. ${ }^{5}$ In one of his largest and most famous homilies, of which the title is lost, ${ }^{6}$ Shenoute refers to the companion angel who protects man. In this sermon, Shenoute preaches to his audience against a rich pagan man called Gesius. Apparently Gesius, who was a man of power in the region, pretended to be a Christian at some point. ${ }^{7}$ Worse, Gesius used to instill disrespect in his servants and prevent them from worshipping God. For Shenoute, the greatest error of this man was that he did not acquire for himself an angel to rescue him from Satan. ${ }^{8}$

The idea of having a companion angel in order to be protected from the evil spirits is quite common and known from elsewhere. For example, in the anecdote of the pious builder, the last story of the first encomium, On Michael and Gabriel, the Archangels $\$ 37-40,{ }^{9}$ the hero of the story spent all his life being faithful to his church. He prays daily before he goes to his work, and only once was he unable to keep his good habit. The angel who protected him left him and immediately he became a weak victim to Satan. The detailed description of how Satan tortured the pious builder in a very savage way serves as a serious warning for those who do not care about their companion angel.

Further passages from Shenoute's works shed more light on the concept of the companion angel. When Shenoute comments on Mark 4:25, he explains that the treasures which everyone should store are good deeds. By these good deeds, one is able to acquire an angel.

\footnotetext{
${ }^{1}$ For a general overview, which is still very useful, see Michl, "Engel I-X". Valuable new insights are offered by Muehlberger, Angels in the Religious Imagination of Late Antiquity.

${ }^{2}$ Müller, Die Engellehre der koptischen Kirche.

${ }^{3}$ van Lent, "The Apocalypse of Shenoute", 182-185.

${ }^{4}$ Amélineau, Monuments pour servir à l'histoire de l'Égypte chrétienne, 347.

${ }^{5}$ The best guide to Shenoute's works is Emmel, Shenoute's Literary Corpus.

${ }^{6}$ Emmel labels it A26, while Behlmer in her edition calls it De iudicio; see Behlmer, Schenute von Atripe: De iudicio.

${ }^{7}$ Gesius is also known from other writings of Shenoute, see Emmel, "Shenoute of Atripe and the Christian Destruction of the Temples in Egypt", 161-201, esp. 194-195.

${ }^{8}$ Behlmer, De iudicio, p. 96-98. The concept that Michael is the protector of the people of God and the opponent of Satan is originally Jewish. It is attested in Rabbinic sources and was later Christianized by Origen, see Hannah, Michael and Christ, 165-166.

${ }^{9}$ Saweros, Another Athanasius, 121-122 (Coptic text), 137-138 (English translation).
}

- 75 - DOI: $10.36816 /$ shedet.006.05 
This angel remains with the person secretly on earth if he remains righteous. The same angel stays with that person until the moment he enters the kingdom of God. ${ }^{1}$ Shenoute assumes that good deeds will help man to acquire an angel with a protective function. The same angel will accompany him throughout his lifetime and protect him during the fearful moment of the true judgment until that person enters the kingdom of God. Shenoute does not mention the opposite scenario: in the case of an evil person, will he acquire an angel? What should this angel do for the evil person? ${ }^{2}$

In the Life of Antony, there are some passages that explain what the companion angel might mean. After a big fight between Antony and the demons, the demons appeared to him in the form of terrifying animals and as beautiful women, in order to remind him of his old way of life. The demons became very angry, tortured him and broke the four walls of his cell down over his head. At that moment, when Antony was near to death and hardly breathing anymore, a ray of light came from the ceiling and spoke with Antony, restoring his body and saving his life. ${ }^{3}$

Usually scholars interpret this ray of light as the Lord and the voice as His voice. But Ellen Muehlberger, with the help of the writings of Ammonas, Antony's successor and the next leader of the same monastic community, has proposed a more convincing interpretation. According to her, the ray of light represents the companion angel, and the moment it came down for Antony was the moment that Antony deserved to receive this angel on account of his good deeds. The angel is supposed to stay with him until the time of the true judgment. ${ }^{4}$ On the other hand, according to many monastic writings, the companion angel will desert the monk if he commits a sin, at which point the monk relapses into his former state or even worse. ${ }^{5}$

\section{THE ANGELS OF THE ALTAR}

In On Murder and Greed and on Michael, the Archangel (the second homily of my dissertation), Pachomius was sitting away from the holy altar, for he was neither a priest nor a deacon. An angel revealed to him a vision of the deacon who was a murderer and unworthy of receiving the Holy Communion (§15-32). ${ }^{6}$ This angel, as it seems to me, may be the companion angel of Pachomius or one of the angels of the altar. The angels of the altar are a group of angels that come down during the Eucharist and surround the priest to guard the sacraments until the end of the Holy Mass and watch the priest while reciting the liturgy. John Chrysostom extensively addressed the angels of the altar in his work, On Priesthood. He claims that only the very pure saints can notice them, such as Pachomius in our story. ${ }^{7}$

The angels during the Eucharist are represented as spectators. John Chrysostom describes them as filled with heavenly powers and existing everywhere around the priest and the altar to honour the sacrifice, i.e. Christ. ${ }^{8}$ This important work had a clear influence on many later writers and theologians. One of them is Narsai of Edessa (d. c. 503). ${ }^{9}$ Narsai assures the

\footnotetext{
${ }^{1}$ Young, Coptic Manuscripts from the White Monastery, 163.

${ }^{2}$ For monastic demonology, see Brakke, Demons and the Making of the Monk, 3-22.

${ }^{3}$ Bartelink, Vie d'Antoine, 142.

${ }^{4}$ Muehlberger, Angels, 92-96.

${ }^{5}$ Muehlberger, Angels, 95-101.

${ }^{6}$ Saweros, Another Athanasius, p. 148-158 (Coptic text), 177-183 (English translation).

${ }^{7}$ Malingrey, Sur le sacerdoce: dialogue et homélie de Jean Chrysostome, 318.

${ }^{8}$ Malingrey, Sur le sacerdoce, 316.

${ }^{9}$ Kazhdan, The Oxford Dictionary of Byzantium, vol. 2, p. 1437-1438; Muehlberger, Angels, 123-124.
} 
holiness and the variety of the angels that share in the Eucharist, including Gabriel and Michael, but he places them in the second position, after the priest, who is the only one to perform the Eucharist. ${ }^{1}$

\section{THE ANGELIC FIGURES AND THEIR TASKS}

One apocryphal text preserved in Coptic, known as The Mysteries of John, the Apostle, ${ }^{2}$ is of great value for the information it presents about the heavenly creatures. The single manuscript was copied in the early eleventh century for the church of Saint Mercurius the General in the district of Edfu. According to the colophon, the copyist was a deacon belonging to a family of scribes and deacons. In the following paragraphs, I will concentrate on this text, because it provides us with rich information about Coptic angelology.

The opening scene of the text describes how the Lord after His resurrection came down to the Mount of Olives and gathered there all his apostles. John was daring enough to ask Christ to take him to Heaven in order to understand its mysteries. After long prayers, the sky opened and a great cherub came down. ${ }^{3}$ The Cherub appeared as a creature whose body is winged and filled with eyes. Christ ordered him to take John into Heaven and explain to him whatever he needed. In the first Heaven, John saw the twelve rulers of the year to whom the mission of yielding crops on earth is assigned. The cherub told John that these twelve rulers are working under the leadership of Michael. When the Father is angry because of the sins of the inhabitants of a certain area of earth, He stops rains there and, consequently, famine follows. In this case, only Michael and his 120,000 angels can beg the Father to have mercy on these people. ${ }^{4}$ Michael always appears as a good intercessor. He prays for the sake of the poor people, even when he knows that they are full of sins. On the other hand, it appears that God chose Michael especially to fulfil this task. Michael is neither assuming this task by his own free will, nor on account of the prayers of the sinful people.

The cherub narrates to John how the first man, Adam, began his life outside of Paradise. Adam and his wife were not able to plant anything and they cried out to God in order to have food. The Son felt sympathy towards them and went before the Father and begged Him to help Adam. The Son was ready to give his own flesh for the sake of Adam. The Father agreed to the Son's wish, and They made the first grain of wheat. Michael, as the messenger of God, had to carry the grain of wheat to Adam and teach him how to sow it. ${ }^{5}$ The same story is quoted in the encomium On Michael and Gabriel, the Archangels \$41-

\footnotetext{
${ }^{1}$ Muehlberger, Angels, 125 .

${ }^{2}$ The manuscript is kept now in the British Library, Or. 7026, from the Esna-Edfu find; Budge, Coptic Apocrypha in the Dialect of Upper Egypt, p. 59-74 (Coptic text), 241-257 (English translation). This text is labeled an 'apostolic memoir'; for more about this literary genre, see Suciu, The Berlin-Strasbourg Apocryphon, 6-11.

${ }^{3}$ Cherubs appear in the Bible for the first time in the Garden of Eden to guard the way to the tree of life (Gen. 3:24). In Ezekiel 10, the four creatures that carry the throne of God are called Cherubim. The same idea is attested in Ps. 18:10 when David says about the Lord: "He mounted the cherubim and flew; he soared on the wings of the wind". In general, the Cherubs are well known in Holy Scripture from descriptions of the Ark of the Covenant and Solomon's temple (1 Kings 6:23-35).

${ }^{4}$ Budge, Apocrypha, 61.

${ }^{5}$ Budge, Apocrypha, p. 62-64. The story that recounts Adam's penance is an ancient one that goes back to the Life of Adam and Eve. For more details, see Haelewyck, Clavis apocryphorum Veteris Testamenti, 1-5.
}

- 77 - DOI: 10.36816/shedet.006.05 
$42,{ }^{1}$ showing how this kind of apocryphal tradition was esteemed and transmitted in monastic communities.

John was lifted up to the seventh Heaven where he saw Michael as the leader of 400,000 angels. These angels were responsible for the dew that falls upon earth. Michael is represented as their active leader. His name is inscribed on the girdles of his fellow angels. These angels call his name all the time for help and answer his demands. Michael is able to handle more than one job at the same time and his leadership is stressed. In addition, John was informed of two significant facts by the cherub. The first is that not all angels are kind; rather, there are groups who perform savage missions assigned to them by God. The second fact is that some angels may make mistakes. ${ }^{2}$ When John asked the cherub why God allowed the devil to get into Paradise and to cause Adam's fall, he answered that Paradise used to be guarded by a couple-dozen angels. As it happened, one group once neglected its work for a while, during which time the devil managed to enter Paradise.

During a long dialogue between John and the cherub, the cherub recounts how angels control the whole nature of the universe: some cherubs are responsible for the twelve hours of every day; a cherub can cause wind to blow or stop it; the sun is in the hand of an angel who moves it along its correct path. All these tasks are performed under the supervision of Michael. ${ }^{3}$

Finally, John's trip to Heaven comes to its end. He returns to the Mount of Olives and tells his colleagues, the apostles, what he has experienced. The image of the angelic world is clearer now: these heavenly creatures do not all have the same functions. They are numberless and divided into many groups, each of which has its own well-defined function. Angels are not always perfect and some may be neglectful in performing their duties and commit errors. Not all of them are kind, but some are assigned the task of avenging the sins of humanity on behalf of God. All work under the leadership of Michael, whose name is written on their garments. If his name is not there, the devil is able to lead them astray. ${ }^{4}$

The general image of the universe is drawn up as follows: God (the ruler) gives orders to Michael (the director) and Michael assigns every angel to his specific task and supervises all angels (the workmen) while carrying out God's orders. Michael is the most powerful creature of all. The whole system of nature is in his hands. Also Shenoute, the most productive Coptic writer, appears to believe that the nature of the universe obeys the rules of the angels. In the fragment Paris BnF $130^{5}$, ff. $134 \mathrm{r}-135 \mathrm{v}$, which is attributed to him, Shenoute describes a vision that was revealed to him. In this vision, Shenoute was told that God controls everything which He created by means of the angels. ${ }^{5}$

Thus, the vision describes an angel whose mission is to provide water for mankind, saying that he is shining like the sun. And when God decides to end someone's life, He asks an angel to go and take the soul of this person out of his body. When the person is evil, God sends Abbaton, who is a huge fearful angelic figure. Abbaton is the main topic of a Sahidic homily attributed to Timothy, Archbishop of Alexandria. This homily provides many

\footnotetext{
${ }^{1}$ Saweros, Another Athanasius, p. 122-123 (Coptic text), 138-139 (English translation).

${ }^{2}$ Budge, Apocrypha, 67.

${ }^{3}$ Budge, Apocrypha, 71.

${ }^{4}$ Budge, Apocrypha, 64.

${ }^{5}$ On this fragment and its attribution to Shenoute, see Emmel, Shenoute's Literary Corpus, vol. 2, 903. It is edited in Leipoldt, Sinuthii archimandritae vita et opera omnia, vol. 4, p. 198-202; see also Grohmann, "Die im Äthiopischen, Arabischen und Koptischen erhaltenen Visionen Apa Schenute's von Atripe”, 32-36.
} 
details about the angel of death and how he was created. ${ }^{1}$ Shenoute, in the above mentioned fragment, describes the angels who are sent to receive the soul of a sinful priest as fearful angels, with changing faces and spitting fire from their mouths (f. 135r).

Various literary Coptic works show us how the souls of sinners are extracted from their bodies. Shenoute, in the same fragment, narrates rather obscurely that the soul is attached to the tail of a donkey. The Bohairic life of Pachomius clarifies Shenoute's vision and adds that fearful angels tie the soul to the tail of a spiritual horse, and thus they take it away and plunge it into torments. ${ }^{2}$ In this view, the angels pull the souls out of the bodies of the evil ones with the help of a spiritual animal.

Later, in the tenth century, an Arabic discourse attributed to Severus of al-Ashmunein (Hermopolis Magna), in which the author seeks to refute the legend of Abbaton, describes the procedure of putting evil people to death. Blood works as a glue that attaches the soul of man to his body. When God sends the fearful angel to the evil one, his blood dries up through fear and the soul becomes free to leave the body. ${ }^{3}$ In any case, it is certain that the Christians of Egypt believed that angels took part in the process of death.

Desspite all these important tasks being attributed to angels in the literature of the church of Egypt, there are a few issues beyond their power and their knowledge. Shenoute, in his famous homily I'm amazed, ${ }^{4}$ discussed the relationship between the Father and the Son. Shenoute states that not even the angels know how the Son proceeded from the Father. ${ }^{5}$

\section{THE ARCHANGEL MICHAEL}

Among the archangels, Michael is considered the first. ${ }^{6} \mathrm{He}$ is the supreme commander of the heavenly hosts. In the Old Testament, Michael is mentioned only a few times. The prophet Daniel experienced a vision after a period of fasting, in which an angel mentions Michael as the protector of Israel and a prince of the first rank. ${ }^{7}$ Later, Daniel refers to Michael as the great prince who is in charge of the people of Israel. ${ }^{8}$ Michael is the patron angel of the Jews, although the statements about him in the Old Testament are rather abstract and vague. In early Jewish sources, Michael is known as the one who heals rather than a fighting angel. ${ }^{9}$

In the New Testament, in Jude 1:9, Michael is given the title of archangel. In Revelation 12:7-12, Michael and his legion combat Satan and his forces and defeat them. ${ }^{10}$ This specific task of Michael is unattested in Jewish sources. In later apocryphal literature, such as the many versions of the Life of Adam and Eve, Michael appears as the one who helps

\footnotetext{
${ }^{1}$ Budge, Coptic Martyrdoms, p. 225-248 (Coptic text), 474-496 (English translation); Saweros and Suciu, "The Investiture of Abbaton, the Angel of Death",526-554.

${ }^{2}$ Lefort, S. Pachomii vita bohairice scripta, p. 90-91; Veilleux, Pachomian Koinonia, vol. I, 109.

${ }^{3}$ Swanson, "The Specifically Egyptian Context of a Coptic Arabic Text", 223; Saweros, "How does the Copt die?"

${ }^{4}$ Emmel, Shenoute's Literary Corpus, vol. 1, 446-448, vol. 2, 794-799; Cristea, Schenute von Atripe: Contra Origenistas, 80-81.

${ }^{5}$ Foat, I Myself Have Seen: The Representation of Humanity in the Writings of Apa Shenoute of Atripe, 138, nr. 0810.

${ }^{6}$ For much of what follows, see Rohland, Der Erzengel Michael.

${ }^{7}$ Dan. 10:13-21.

${ }^{8}$ Dan. $12: 1$.

${ }^{9}$ Rohland, Der Erzengel Michael, 32-33.

${ }^{10}$ Guiley, The Encyclopedia of Angels, p. 242-249; Michl, "Michael”, cols. 243-251.
} 
people to overcome their problems, their pains and their diseases. Such non-canonical writings, which developed in dependence on Biblical actors and Biblical events, present a clearer, more detailed and colourful image of Michael than the Bible itself does. ${ }^{1}$ The image of Michael as the heavenly fighter, as described in the Book of Revelation, was expanded later by the writers of the apocrypha and then by the Church fathers. Origen developed the idea that Michael can intervene in an earthly battle in his comments on Joshua 5:14. Thus, the idea of Michael as a helper of mankind started to spread. ${ }^{2}$

The cult of Michael as a healer of the sick, which has its roots in the Jewish tradition, was known in Egypt since the fourth century. At this early stage of the spread of Christianity in Egypt, Michael seems to be the equal of the ancient Egyptian gods that are called upon by certain magical spells to provide healing and protection against evil spirits. Actually, in several cases, the Christians of Egypt interchange his name with those of their ancient gods as a source of healing. ${ }^{3}$ Such texts are witness to the intersection of Egyptian, Jewish and Christian traditions. In a later period, many other perceptions of Michael became apparent; for example, as the one who favours military leaders and guides them towards the Christian faith. Therefore, in later times, his image was carried before the Christian armies. ${ }^{4}$ After Origen, the Church fathers did not support the idea of Michael as a healer. They ascribed the same function to Christ as the only doctor for humanity. ${ }^{5}$ It seems that the cult of Michael followed two paths, one for the higher classes and another for the lower classes. The upper classes saw him primarily as a heavenly creature, who played an important role with believers after death and in Heaven. For the lower classes, Michael was an intercessor and a messenger of God, able to lend his help in many positive ways upon earth and always available to be called upon. ${ }^{6}$

In the Coptic tradition, Michael is known as the one who leads the souls of the dead to Heaven, the one who presents the prayers of the righteous people to the Lord and the one who leads the heavenly creatures. ${ }^{7}$ The Coptic Church celebrates him on the twelfth day of every month, especially on the twelfth of Hathyr and Pauni. His main feast, the twelfth of Hathyr, is connected with his inauguration in replacement of Satan who refused to worship Adam. This story is known, among many other sources, from The Book of the Investiture of Michael, an apocryphal text attributed to St. John, the Apostle. ${ }^{8}$ This book was criticized later by John of Parallos, ${ }^{9}$ but is nevertheless a key witness to the cult of Saint Michael in Christian Egypt. ${ }^{10}$

The numerous homilies on Michael surviving in Coptic also reflect his importance in the religious life of the Christians of Egypt through the ages. Most of these homilies do not represent Michael to their audiences nor do they provide further data about his role in

\footnotetext{
${ }^{1}$ Rohland, Der Erzengel, 48-49.

${ }^{2}$ Rohland, Der Erzengel, 74.

${ }^{3}$ For example, see Meyer and Smith (eds.), Ancient Christian Magic, 83-81; Rohland, Der Erzengel, $103-104$.

${ }^{4}$ Rohland, Der Erzengel, 136.

${ }^{5}$ Rohland, Der Erzengel, 147.

${ }^{6}$ Rohland, Der Erzengel, 147-148.

${ }^{7}$ van Esbroeck, "Saint Michael the Archangel", 1616-1620.

${ }^{8}$ This text is preserved in Sahidic and Fayoumic; Müller, Die Bücher der Einsetzung der Erzengel Michael und Gabriel, 2-60 (Coptic text), 1-78 (German translation); an English translation by Antony Alcock has appeared online recently via https://www.academia.edu/30100434/The Investiture of Michael the Archangel.

9van Lantschoot, "Fragments coptes d'une homélie du Jean de Parallos", 296-326.

${ }^{10}$ van Esbroeck, Saint Michael, p. 1618.
} 
Heaven. However, a few do, and all of these praise the cult of Michael, in addition to urging people to honour him. Principally, these include the homilies attributed to St. Eustathius of Trake, ${ }^{1}$ to Saint Macarius of Tkow, ${ }^{2}$ and to Timothy II, Patriarch of Alexandria. $^{3}$

Homilies from the same collection - the Hamuli codices, to which the set of homilies I edited in my dissertation belong - may shed more light on the role of Michael and Gabriel. In a Sahidic homily on Michael attributed to John Chrysostom, Michael is described as the first in rank, prince of the whole army of angels. Among his innumerable other tasks, Michael will sound the trumpet before the divine king at the time of the true judgment, a feature that is remarkable and attested only here. John Chrysostom advises everyone to liken himself to the angels and to try to be a friend of them. Monks should follow the angels as a model in their struggle for the sake of perfection. ${ }^{4}$

Pseudo-Basil of Caesarea, in his first homily on Michael, which it is said to have been delivered at Lasike, ${ }^{5}$ starts to praise the people gathering at the shrine of Michael in order to worship him. The homily describes the function of Michael as follows: "Michael oversees every command of the Lord. He is the chief of the Lord's force, since he assigns every angel to his service, just as a general who receives letters from the king and appoints each man to his company. He is full of mercy, more than the entire angelic host. ${ }^{6}$

Pseudo-Basil explains the idea of the protector angel in simple, direct words: "When the angel of the Lord watches over people, how the devil will have power over them? It is impossible for light and darkness to have fellowship with each other". 7 The homily also refers to the indescribable powers of every single angel, adding that he is able to destroy the world if God orders. He warns his listeners not to beg the angels, but the angels' creator, for the angels were created to act as our friends and servants. ${ }^{8}$

\footnotetext{
${ }^{1}$ Preserved in Sahidic and Bohairic; Budge, Saint Michael the Archangel, 93-135; Campagnano, Maresca, and Orlandi. Quattro omelie copte, 107-172.

${ }^{2}$ Lafontaine, "Un éloge copte de Saint Michel”, 301-320.

${ }^{3}$ Budge, Miscellaneous Coptic Texts in the Dialect of Upper Egypt, 512-525 (Coptic text), 1021-1033 (English translation). The only work that has attempted to review all these sources on Michael is Müller, Die Engellehre, 12-34

${ }^{4}$ Brakke, "Homily on St. Michael Archangel attributed to John Chrysostom", vol. 1, 47-55 (Coptic text), vol. 2, 48-56 (English translation).

${ }^{5}$ Perhaps the Greek Lakiza; see Orlandi and Campagnano, Vite dei monaci Phip e Longino, 58-59.

${ }^{6}$ Smith, "First Homily on St. Michael Archangel", vol. 1, 10-16 (Coptic text), vol. 2, 10-17 (English translation).

${ }^{7}$ Smith, "First Homily", 14.

${ }^{8}$ Smith, "First Homily", 16.
} 
In his second homily on Michael, which he is said to have delivered at Lasike as well, pseudo-Basil repeats his description of the dignity of Michael as the first of rank among the angelic hosts. He says that people respect the one who works beside the emperor, and as Michael is the closest one to the Lord, how much respect should he deserve? The author of the homily makes Michael describe himself by his own tongue. Michael says: "I am bodiless and living in purity, singing songs of praise to the undefiled one. I, on my part, have more authority in Heaven to intercede on your behalf than all the saints". ${ }^{1}$ This is the first time that Michael himself speaks about his role in Heaven. It is clear now that he is the first not only among the angels, but among all saints. He is sure that his intercession will make a difference for the believers. This is not so strange in a homily composed to be delivered on Michael's feast that urges the listeners to present their offerings and tithes to a church where Michael is venerated.

In the same homily, Michael says: "Since angels and men have but this one Lord and it is He who created them both, let your deeds be found to resemble ours. Keep your bodies pure on earth and I will intercede on behalf of you in the seventh Heaven". ${ }^{2}$ In these final passages of pseudo-Basil's homily, Michael just repeats pseudo-Basil's thoughts. Michael praises the people gathered at his sanctuary, speaks against fornication and encourages people to stay undefiled, for the impure lacks holy life. Finally, Michael explains how successful his intercession in front of the Lord is. Pseudo-Basil emphasizes that the angels are able to hear the prayers of men and refers also to the presence of the angels during the Holy Mass. ${ }^{3}$

In the introduction of a Sahidic homily attributed to Macarius of Tkow, also found in the Hamuli codices, Macarius preaches to his congregation two main ideas. It seems that these ideas started to become quite common and that the preacher has to mention them in order to attract the attention of his audience, before he moves onto the major themes of his homily. The first theme concerns the reason why they celebrate Michael on the twelfth of Hathyr. The answer is because this is the day on which Michael replaced Satan in Heaven (f. 27v$28 \mathrm{r}),{ }^{4}$ exactly as The Book of the Investiture of Michael states. The second theme stresses the difference between the intercession of Michael and the rest of the saints, more or less as the second homily of pseudo-Basil did. Michael's mediation is not limited to a certain area, whereas the other saints' intercessions are limited to their own people (f. $28 \mathrm{v}$ ). ${ }^{5}$

Macarius adds more details to let his listeners honour Michael and work hard to satisfy him. He relates that Michael is the friend of the prophets and the patriarchs, the helper of the pious kings and the guide of the judges (f. 29r). ${ }^{6}$ In his warnings against fornication, he presents Michael to his listeners as a model of purity that everyone should follow. Since sins make Michael angry, especially on the day of his feast, we need to refrain from committing sins in order to make Michael's heart happy. Thus, we can benefit from his mediation (f. 30r). ${ }^{7}$

\footnotetext{
${ }^{1}$ Smith, "Second Homily on St. Michael Archangel", vol. 1, p. 17-23 (text), vol. 2, p. 18-24 (translation).

${ }^{2}$ Smith, "Second Homily", 22.

${ }^{3}$ Smith, "Second Homily", 21.

${ }^{4}$ Lafontaine, "Un éloge copte", 303-304.

${ }^{5}$ Lafontaine, "Un éloge copte", 304.

${ }^{6}$ Lafontaine, "Un éloge copte", 305.

${ }^{7}$ Lafontaine, "Un éloge copte", 305-306.
} 
Leaving the domain of the Hamuli codices, a Bohairic homily attributed to John Chrysostom expands the role of Michael as an important intercessor. ${ }^{1}$ John Chrysostom places Michael in the same rank as the holy Virgin Mary. Thanks to the prayers of Mary and Michael, God grants men sleep at night and allows them some respite from their labours. Mary and Michael beg God to send wind to the earth to help those travelling by water and ask Him to preserve the earth from storms. Pseudo-John Chrysostom presents Michael in a new role, when he makes him pray that God may fill all the deserts and mountains with monks and ascetics (f. $29 \mathrm{v}$ ). ${ }^{2}$ The same homily refers to another feast of Michael, dedicated to the celebration of the consecration of his church in Alexandria (thought to be the former temple built by Queen Cleopatra VII for her son Caesarion ${ }^{3}$ ). The same story is reflected in the Coptic Synaxarion. ${ }^{4}$

Pseudo-John Chrysostom counts twelve occasions on which Michael descended to the earth in order to accomplish divine missions (f. 26v-29r). ${ }^{5} \mathrm{~A}$ few of these deserve to be mentioned here. Michael appeared to Jacob before he had the dream about the ladder erected between earth and Heaven. ${ }^{6}$ Michael descended to the earth to announce the birth of Samson $^{7}$ and release a plague upon the earth. ${ }^{8} \mathrm{He}$ also appeared to announce the rise of Nebuchadnezzar, the king of Babylon, who would take the sinful king Jehoiakim in fetters as a captive. ${ }^{9}$ Michael revealed to Daniel the king's dream. ${ }^{10}$ The last job of Michael seems to be parallel to $\S 41$ of the encomium, On Michael and Gabriel, the Archangels, ${ }^{11}$ although the name of Daniel is missing due to the lacuna. Apparently, pseudo-John Chrysostom uses the name of Michael to explain many Biblical anecdotes where no other explanation is given. Whenever in the Bible a miraculous event is told, Michael should be behind it. In this way, apparently, the author tries to convince his congregation of the supreme role of Michael.

Judging from the title and the introduction of the encomium On Michael and Gabriel, the Archangels, everyone who will purify himself and come to present his offerings to the shrines of Michael and Gabriel will receive a reward in Heaven. In the remainder of the encomium, Michael and Gabriel appear as archangels who support pure people during their life. The angelic support may take many different forms. Michael and Gabriel may harm the perpetrators of evil as they did in the narrative of the Arian George $\$ 13-15{ }^{12}$ The archangels may support innocent people by revealing the faults of the sinners. Thus, they reveal the fraud of the rich man from Pentapolis $\$ 16-20 .^{13}$

\footnotetext{
${ }^{1}$ J. Simon, “Homélie copte inédite sur S. Michel”, Orientalia 3, p. 217-242 (Coptic text); Orientalia 4, 1935, 222-234 (French translation).

${ }^{2}$ Simon, Orientalia 3, 235; Orientalia 4, 229.

${ }^{3}$ Simon, Orientalia 3, 234-235; Orientalia 4, 228-229.

${ }^{4}$ Basset, Le synaxaire arabe jacobite, 556-561.

${ }^{5}$ Simon, Orientalia 3, 230-234; Orientalia 4, 225-228.

${ }^{6}$ Gen. 28:12.

${ }^{7}$ Judg. 13:1-5.

${ }^{8}$ Perhaps the one mentioned in 1 Ch. 21:9-17.

${ }^{9} 2$ Ch. 36:5- 21.

${ }^{10}$ This apocryphal story is also known from another fragment: Crum, "Texts Attributed to Peter of Alexandria", 395-397.

${ }^{11}$ Saweros, Another Athanasius, 122-123 (Coptic text); 138 (English translation).

${ }^{12}$ Saweros, Another Athanasius, 110-111 (Coptic text); 129-130 (English translation).

${ }^{13}$ Saweros, Another Athanasius, 112-114 (Coptic text); 130-131 (English translation).
}

- 83 - DOI: $10.36816 /$ shedet.006.05 
In order to urge his congregation to gather on the feast day of Michael and Gabriel, to venerate them and share in the festivities and in the celebration of the holy mass, the author insists on persuading his audience that the angels display greater efforts on the occasion of their feast. They may appear to any righteous one and help the oppressed ones on the eve of the twelfth of Hathyr. The author of this encomium does not make a big difference between Michael and Gabriel, except that Michael is always involved in benevolent missions. However, when God wants to take revenge on evil people, He assigns such missions to Gabriel.

Michael appears in the encomium as a strong and fast intercessor that people beg for help, especially on his feast day. Michael repeatedly asks God to have mercy on humanity. Towards the end of the encomium, the author describes Michael as a messenger of God who sends him on privileged missions. In the epilogue, the author narrates very briefly what we can call a short history of Michael and Gabriel. He claims, for instance, that Michael was sent to Adam when he was in the waters of Jordan in order to give him the seed of life, a story deriving directly from the well-known apocryphal tradition quoted above. ${ }^{1}$

In the second homily, On Murder and Greed and on Michael, the Archangel, the author begins by praising the feast of Michael on the twelfth of Hathyr. Michael is the reason for the assembly of the people and they should sing spiritual hymns that express their happiness. People should follow God's commandments and respect the Church for the sake of Michael, who is serving them. The introduction of the homily aims to attract the attention of the audience to the supreme importance of Michael, the main subject of the homily $§ 1-2 .^{2}$

The author of the homily goes on to narrate two visions of Saint Pachomius which occupy most of the homily, before finally returning to Michael. The author, in the personality of Athanasius, describes in detail how Michael looked when he appeared to him to console him during his exile in Upper Egypt $§ 43-49 .{ }^{3}$ Michael, as described by pseudo-Athanasius, is a huge heavenly creature, the greatest in Heaven and no one owns the same glory as his. $\mathrm{He}$ is portrayed as a very fearful creature, with wings, each of which is five cubits long. $\mathrm{He}$ wears a cloak of fire and his legs are brazen like bronze that is melted in a furnace. A great luminous staff is in his right hand and a sword of fire in his left hand. His eyes and face produce flashes of fire. ${ }^{4}$

This appearance was frightening enough to make Athanasius fall down upon his face. Michael then drew close to him, consoled him and told him that his period of exile was nearing its end and that he would return to his see very soon. In this part of the homily, the author again focuses on Michael as a messenger of God and a supporter of the righteous believer. Moreover, his revelation reflects the heavenly attitude towards the Arians, who are the cause of Athanasius' exile. The message of the homily is clear to its audience, Michael is supporting the adherents of the true faith, namely Athanasius and his followers.

${ }^{1}$ See Budge, Coptic Apocrypha, pp. 63-64; Müller, Die Bücher der Einsetzung, 70; Müller, Die Engellehre, 21.

${ }^{2}$ Saweros, Another Athanasius, 141-142 (Coptic text); 171-172 (English translation).

${ }^{3}$ Saweros, Another Athanasius, 164-168 (Coptic text); 188-191 (English translation).

${ }^{4}$ Descriptions of angels as fiery figures are well attested in Holy Scripture; see, for example Ps. 103:4 (LXX). 
Apparently, Michael is dedicated to this mission of consoling bishops in exile or in trouble. As far as we know, the same is told about Peter of Alexandria, ${ }^{1}$ Severus of Antioch, ${ }^{2}$ Macarius of $\mathrm{Tkow}^{3}$ and many more. ${ }^{4}$ It seems that around the time that the homily $\mathrm{On}$ Murder and Greed and on Michael, the Archangel was copied at Saint Michael's monastery in the Fayoum, in the early tenth century, this tradition was quite common, although the tradition is much older.

In other sources, Michael appears as the companion of saints and martyrs. Examples from hagiographic texts, in which he consoles the martyrs and relieves the bodily pains inflicted by their persecutors, are numerous. Even in their martyrdoms, Michael is the closest friend of the martyrs. He comes fast and prepares the way to Paradise. ${ }^{5}$ Usually, towards the end of the life of the martyr, Christ himself descends to receive the soul of the martyr, accompanied by Michael, Gabriel and a host of angels. Michael cures the body of the martyr on behalf of Christ, which is the principal action of the whole episode. By singing hymns, the other angels show that Heaven is pleased because of the martyrdom of the new saint. ${ }^{6}$

Sometimes, Michael appears as a miracle-maker who is sent by God to help people, working as the opponent of the pagan magicians. In some of these miraculous stories, he appears as a governor or an important man riding on horseback and his appearance aims in general to strengthen the faith of someone, stop the evil deeds of another and provide services to those in distress. In all these cases, Michael's target is not a saint or a martyr, but normal believers. Sometimes, Michael and his host of angels are shown climbing up to the sky to emphasise that their support is a special gift of Heaven. ${ }^{7}$

The most common ideas that these homilies share about Michael is that he is the first in rank among all the angelic figures. He is always involved in kind missions, appearing as a friend of righteous people, blessing pure ones and revealing the sins of evil doers.

\section{THE ARCHANGEL GABRIEL}

The first angel mentioned by name in the Old Testament is Gabriel in the Book of Daniel. ${ }^{8}$ Not only does this angel have the privilege of being the first to be mentioned by name, Gabriel also shares with Michael the privilege of being one of the few angels mentioned in the Bible. The archangel Gabriel also interacts with Zechariah and Mary in the New Testament, as the angel who announces the births of John the Baptist and Jesus, respectively. Luke uses Gabriel as a bridge between the Old and the New Testaments that brings events and characters from the Hebrew Bible to the life of Jesus. ${ }^{9}$

\footnotetext{
${ }^{1}$ Vivian, St. Peter of Alexandria, 1-40.

${ }^{2}$ Budge, St. Michael, 63-91.

${ }^{3}$ Johnson, A Panegyric on Macarius Bishop of Tkôw, 1-80.

${ }^{4}$ Most of these visions are collected in Youssef "The Archangel Michael and the Patriarchs in Exile", 646647.

${ }^{5}$ Müller, Die Engellehre, 24.

${ }^{6}$ Müller, Die Engellehre, 25.

${ }^{7}$ Müller, Die Engellehre, 28.

${ }^{8}$ Dan. 8:15-19.

${ }^{9}$ Luke 1:11-38.
}

- 85 - DOI: $10.36816 /$ shedet.006.05 
According to Coptic tradition, Gabriel is one of the seven archangels who work under the leadership of Michael. Sometimes, he is considered the third among the heavenly hosts. ${ }^{1}$ His name is derived from Hebrew and means "mighty man of God". ${ }^{2}$ The Coptic Church celebrates Gabriel on the thirtieth of Pharmouthi and thirteenth of Pauni. ${ }^{3}$ The homilies dedicated to Gabriel provide scarce information about his roles in Heaven. Moreover, these homilies have reached us in a fragmentary state. ${ }^{4}$ Thus, we cannot understand clearly the relationship between Michael and Gabriel. We know that Michael is number one among the archangels and Gabriel is close to him in rank, but it is difficult to see whether Michael has authority over Gabriel and can assign certain missions to him or not. Sometimes, even the titles and functions of each are confused. Both are called messengers of life, victorious in the good battle and appointed over all saints. ${ }^{5}$

From the few homilies dedicated to Gabriel, he is known as the angel of peace and the defender of the just. ${ }^{6} \mathrm{He}$ is the leader of a large number of angels. ${ }^{7}$ Gabriel, according to these homilies, is responsible for certain missions on earth. He appeared to Abraham to announce him that he will beget a son, ${ }^{8}$ and to the martyrs to console them during persecution. ${ }^{9}$ Gabriel is also known as the one who protects the souls against the fearful powers of evil that may attack them during their journey to Heaven after death. ${ }^{10}$

In spite of being high in rank, the importance of the archangel Gabriel in the Coptic tradition is significantly less than that of Michael. ${ }^{11}$ Sometimes, the name of Gabriel appears beside that of Michael, and they are asked to heal somebody through a magical spell to be worn by the sick person. On other occasions, Gabriel is asked to do the opposite, to cast curses and diseases upon the enemy of the one who uses the magical spell. ${ }^{12}$

Gabriel mostly appears on the left hand of Christ, singing hymns. He is a figure of light, filling every place he enters with light and a pleasant fragrance. He has mighty, large wings. Sometimes, he appears as the leader of a host of 24,000 angels. ${ }^{13}$ As mentioned in Luke 1, Gabriel is primarily a messenger of God, who sends Gabriel on specific missions or to perform a miracle for the sake of a righteous person. He would appear to those who built a church in his name. Gabriel is also a guarantor, whom people involve in their business deals as a witness, to punish mercilessly the one who breaks the terms of the agreement. ${ }^{14}$ Here, the other side of Gabriel appears, as a tool of punishment in the hand of God. In the encomium On Michael and Gabriel, the Archangel $\S 16-20,{ }^{15}$ he appears as a fearful angel in the story of the son of the rich man from Pentapolis. In this story, Gabriel is described as a flame of fire that is ready to destroy the evil ones and frighten them.

\footnotetext{
${ }^{1}$ Perez, "Archangel Gabriel”, 1135-7; Michl, "Gabriel”, cols. 239-243.

${ }^{2}$ Michl, "Gabriel", 239-240.

${ }^{3}$ Basset, Le synaxaire, vol. IV, p. 913-914; vol. V, p. 1105-1106.

${ }^{4}$ Depuydt, Catalogue of Coptic Manuscripts in the Pierpont Morgan Library, 189-190.

${ }^{5}$ Depuydt, Catalogue, 215; Müller, Die Engellehre, 61-63.

${ }^{6}$ Müller, Die Engellehre, 36-44; Förster, "Streck dich nicht mit einer Verheirateten", 273-305.

${ }^{7}$ Müller, Die Bücher, 14-17.

${ }^{8}$ Müller, Die Bücher, 22-24.

${ }^{9}$ Müller, Die Bücher, 24-26.

${ }^{10}$ Perez, "Archangel", 1136.

${ }^{11}$ Müller, Die Engellehre, 38.

${ }^{12}$ For example, Meyer and Smith (eds.), Ancient Christian Magic, 51-51, 55-56, 83-84.

${ }^{13}$ Müller, Die Engellehre, p. 40.

${ }^{14}$ Müller, Die Engellehre, 43. See also Depuydt, Catalogue, 191-193.

${ }^{15}$ Saweros, Another Athanasius, 112-114 (Coptic text); 130-131 (English translation).
} 
To broaden our view of Gabriel, the so-called Apocalypse of Enoch is an important source, which is preserved in three versions, referred to by their principal languages: Ethiopic, Slavonic and Hebrew. ${ }^{1}$ Through these versions, Gabriel's functions can be better understand and defined. The roles attributed to Gabriel vary greatly, and they range from a destroyer (of the bastard children of the Watchers, as well as of Sodom), ${ }^{2}$ to an interpreter and messenger (explaining the future plan of God), ${ }^{3}$ and an overseer of Heaven and a guide who brings Enoch into the presence of God. ${ }^{4}$

Gabriel is represented as the guardian of the Garden of Eden. He is called one of the princes who guide the world. ${ }^{5}$ The sixth Heaven is under the responsibility of his hosts. ${ }^{6}$ From the books of Enoch, then, one better understands the roles ascribed to Gabriel, even though these books tend to describe Gabriel as an angel with whom we are supposed to be familiar already. Within these apocalyptic texts, the angels give humanity a glimpse of God's master plan and inform about the salvation to come.

The author of the encomium On Michael and Gabriel, the Archangels appears not to distinguish between the two archangels, because he intended the homily to be read on the twelfth of Hathyr, the feast day of both archangels, according to his belief. Gabriel shares with Michael the mission of protecting the Orthodox faith. According to the same encomium, Gabriel is assigned to missions related to charity and offerings, and he brings what people present directly to God.

Interestingly, the appearance of Michael as described in the homily On Murder and Greed and on Michael, the Archangel, $\$ 43-49^{7}$ closely resembles the description of Gabriel given in the so-called Life of Aur. This Arabic text comes from the Monastery of Saint Gabriel at Naqlun, in the same region as the Hamuli codices, and may have been part of the same tradition. Gabriel is described as a heavenly creature with large wings, holding in his one hand a staff of gold and in the other a sword, while his legs resemble brazen copper. ${ }^{8}$ It seems that the Copto-Arabic tradition retained the same mental image of the angels' outward appearance through the ages. In turn, this image is inspired by the description of Christ in the Book of Revelation. ${ }^{9}$

\section{CONCLUSION}

Three questions about the angels should be answered, those of their nature, job and rank. Concerning their nature, Coptic tradition depended on what the Bible provides about the nature of angels. They are fiery, bodiless creatures, much larger than human size and winged. In this respect, Michael, Gabriel and the rest of angels may look the same. In rank,

\footnotetext{
${ }^{1}$ Mostly dated from the $1^{\text {st }}$ century $\mathrm{BC}$ to the $6^{\text {th }}$ century AD; Charlesworth (ed.), The Old Testament Pseudepigrapha, vol. I, 6-7, 94-95, 225-229.

${ }^{2}$ Ethiopic Apocalypse of Enoch, 10:9a.

${ }^{3}$ Slavonic Apocalypse of Enoch, 71:11b.

${ }^{4}$ Slavonic Apocalypse of Enoch, 21:5.

${ }^{5}$ Hebrew Apocalypse of Enoch, 14:4.

${ }^{6}$ Hebrew Apocalypse of Enoch, 17:3b.

${ }^{7}$ Saweros, Another Athanasius, 164-168 (Coptic text); 182-191 (English translation).

${ }^{8}$ ten Hacken, The Legend of Saint Aūr, 217-218.

${ }^{9}$ Rev. 1:10-19.
}

- 87 - DOI: $10.36816 /$ shedet.006.05 
there are seven leaders. Michael is one of the seven and their leader. Gabriel is close to Michael in rank, always following him in rank whenever they are mentioned altogether.

The jobs ascribed to Michael and Gabriel are difficult to distinguish, as one may replace the other in achieving a certain mission. Both are messengers of God, fulfilling his good will on earth, and both are intercessors for humans before the Lord. The two archangels, Michael and Gabriel, support righteous people. Few missions are ascribed to Michael that Gabriel cannot do, whether leading all the heavenly troops, receiving direct orders from God or assigning every angel their tasks. On the other hand, exacting revenge on evil people is ascribed to Gabriel alone.

In general, the first and the second homilies edited in my dissertation do not contribute substantially to our knowledge of angels in the Coptic tradition. Yet, one should note the abilities of the authors of these homilies in using their limited knowledge of angels to carefully deliver their moral lessons. These authors achieved three goals by narrating one single story about angels. They simultaneously engage the imagination of their listeners, celebrate Athanasius and give authority to their messages. 


\section{REFRENCES}

- Amélineau (Emile), Monuments pour servir à l'histoire de l'Égypte chrétienne aux IV ${ }^{e}, V^{e}, V I^{e}$, et VII' siècles, vol. 2, Paris, 1895.

Bartelink (Gerhardus), Vie d'Antoine, Sources chrétiennes 400, Paris, 1994.

- Basset (René), Le synaxaire arabe jacobite, rédaction copte: V, Les mois de baounah, abib, mesoré et jours complémentaires, Patrologia Orientalis 17, 1923.

- Behlmer (Heike), Schenute von Atripe: De iudicio (Torino, Museo Egizio, Cat. 63000, Cod. IV), Turin, 1996.

- Brakke (David), "Homily on St. Michael Archangel attributed to John Chrysostom", in Depuydt, L. (ed.), Homiletica from the Pierpont Morgan Library, (CSCO 524-525), Louvain, 1991, vol. 1, 47-55, vol. 2, 48-56.

- _ _ Demons and the Making of the Monk: Spiritual Combat in Early Christianity, Cambridge, 2006.

- Budge (Wallis), Saint Michael the Archangel: Three Encomiums by Theodosius, Archbishop of Alexandria, Severus Patriarch of Antioch and Eustathius Bishop of Trake, London, 1894.

- Budge (Wallis), Coptic Apocrypha in the Dialect of Upper Egypt, London, 1913.

- _ _ C Coptic Martyrdoms, etc. in the Dialect of Upper Egypt, London, 1914.

- _ _ Miscellaneous Coptic Texts in the Dialect of Upper Egypt, London, 1915.

- Campagnano (Antonella), Maresca (Antonella) and Orlandi (Tito), Quattro omelie copte. Vita di Giovanni Crisostomo, Encomi dei 24 Vegliardi (Ps. Procle e Anonimo), Encomio di Michele Arcangelo di Eustazio di Tracia, Milan, 1977.

- Charlesworth (James) ed., The Old Testament Pseudepigrapha, vol. I: Apocalyptic Literature and Testaments, New York, 1983.

- Cristea (Hans-Joachim), Schenute von Atripe: Contra Origenistas. Edition des koptischen Textes mit annotierter Übersetzung und Indizes einschließlich einer Übersetzung des 16. Osterfestbriefs des Theophilus in der Fassung des Hieronymus (ep. 96), Studien und Texte zu Antike und Christentum 60, Tübingen, 2011.

- Crum (Walter), "Texts Attributed to Peter of Alexandria", JThS 4, (1902-1903) 395-397.

- Depuydt (Leo), Catalogue of Coptic Manuscripts in the Pierpont Morgan Library, Louvain, 1993.

- Emmel (Stephen), Shenoute's Literary Corpus, 2 vols., (CSCO 599-600), Louvain, 2004. , "Shenoute of Atripe and the Christian Destruction of the Temples in Egypt: Rhetoric and Reality", in Hahn, J. et al (eds.), From Temple to Church: Destruction and Renewal of Local Cultic Topography in Late Antiquity, Leiden (2008) p. 161-201.

- Foat (Michael), I Myself Have Seen: The Representation of Humanity in the Writings of Apa Shenoute of Atripe, PhD-dissertation, Brown University, 1996.

- Förster (Hans), "Streck dich nicht mit einer Verheirateten zum Weingelage hin (Sir 9,9a). Edition von P. Vindob. K. 9670", Zeitschrift für Antikes Christentum 14 (2010), 273-305.

- Grohmann (Adolf), "Die im Äthiopischen, Arabischen und Koptischen erhaltenen Visionen Apa Schenute's von Atripe: Text und Übersetzung”, ZDMG 68 (1914), 1-46.

- Guiley (Rosemary), The Encyclopedia of Angels, 2nd ed., New York, 2004.

- Haelewyck (Jean-Claude), Clavis apocryphorum Veteris Testamenti, Turnhout, 1998.

- Hannah (Darrell), Michael and Christ: Michael Traditions and Angel Christology in Early Christianity, Tübingen, 1999. 
- Johnson (David), A Panegyric on Macarius Bishop of Tkôw Attributed to Dioscorus of Alexandria, (CSCO 415), Louvain, 1980.

- Kazhdan (Alexander) ed., The Oxford Dictionary of Byzantium, vol. 2, Oxford, 1991.

- Lafontaine (Jean), 'Un éloge copte de Saint Michel, attribué à Macaire de Tkow”.Le Muséon 92 (1979) 301-320.

- Lefort (Louis), S. Pachomii vita bohairice scripta, (CSCO 89), Paris, 1925.

- Leipoldt (Iohannes), Sinuthii archimandritae vita et opera omnia, vol. 4, (CSCO 73), Louvain, 1954.

- Malingrey (Anne-Marie), Sur le sacerdoce: dialogue et homélie de Jean Chrysostome, introduction: Texte critique, traduction et notes, Paris, 1980.

- Meyer (Marvin) and Smith (Richard) eds., Ancient Christian Magic: Coptic Texts of Ritual Power, Princeton, 1999.

- Michl (Johann), "Engel I-X”, Reallexikon für Antike und Christentum, vol. 5, Stuttgart (1962) 53-258.

, "Gabriel", Reallexikon für Antike und Christentum, vol. 5, Stuttgart (1962), 239-243. 243-251.

- Muehlberger (Ellen), Angels in the Religious Imagination of Late Antiquity, PhD-dissertation, Indiana University, 2008.

- Müller (Caspar), Die Engellehre der koptischen Kirche: Untersuchungen zur Geschichte der christlichen Frömmigkeit in Ägypten, Wiesbaden, 1959.

Die Bücher der Einsetzung der Erzengel Michael und Gabriel, (CSCO 225226), Louvain, 1962.

- Orlandi (Tito) and Campagnano (Antonella), Vite dei monaci Phip e Longino, Milan, 1975.

- Pérez (Gonzalo), “Archangel Gabriel”, in The Coptic Encyclopedia IV, New York, 1991, 11351137.

- Rohland (Johannes), Der Erzengel Michael: Arzt und Feldherr, Leiden, 1977.

- Saweros (Ibrahim), Another Athanasius: Four Sahidic Homilies attributed to St. Athanasius of Alexandria: Editions, Translations and Introduction, PhD-dissertation, Leiden University, 2016. , "How does the Copt die? A study of the Angel of Death in the Coptic Tradition together with a Critical Edition of the Ninth Chapter of Kitab al-Idah attributed to

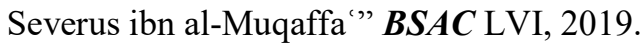

- Saweros (Ibrahim) and Suciu (Alin), "The Investiture of Abbaton, the Angel of Death: A New Translation and Introduction", in Burke, T. and Landau, B., New Testament Apocrypha: More Non-Canonical Scriptures, vol. 1, Michigan (2016) 526-554.

- Simon (Jean), "Homélie copte inédite sur S. Michel et le Bon Larron, attribuée à S. Jean Chrysostome", Orientalia 3 (1934) 217-242; Orientalia 4 (1935) 222-234.

- Smith (James), "First Homily on St. Michael Archangel delivered at Lasike, attributed to Basil of Caesarea", in Depuydt, L. (ed), Homiletica from the Pierpont Morgan Library, (CSCO 524-525), Louvain, 1991, vol. 1, 10-16, vol. 2, 10-17.

, "Second Homily on St. Michael Archangel delivered at Lasike, attributed to Basil of Caesarea", in Depuydt, L. (ed.), Homiletica from the Pierpont Morgan Library, (CSCO 524-525), Louvain, 1991, vol. 1, 17-23, vol. 2, 18-24.

- Suciu (Alin), The Berlin-Strasbourg Apocryphon: A Coptic Apostolic Memoir, Tübingen, 2017. 
- Swanson (Mark), "The Specifically Egyptian Context of a Coptic Arabic Text: Chapter Nine of the Kitab Al-Idah of Sawirus Ibn Al-Muqaffa", Medieval Encounters 2 (1996) 211-227.

- ten Hacken (Clara), The Legend of Saint Aūr and the Monastery of Naqlūn: The Copto-Arabic Texts, PhD-dissertation, Leiden University, 2015.

- van Esbroeck (Michel), "Saint Michael the Archangel", in The Coptic Encyclopedia V, New York, 1991, 1616-1620.

- van Lantschoot (Arnold), "Fragments coptes d'une homélie du Jean de Parallos contre les livres hérétiques", in Mohlbert, L. C. et al. (eds.), Miscellanea Giovanni Mercati I, Studi e Testi 121, Vatican City, (1946), 296-326.

- van Lent (Jos), "The Apocalypse of Shenoute", in Thomas, D. et al (eds.), Christian-Muslim Relations: A Bibliographical History, vol. 1, Leiden, 2009, p. 182-185.

- Veilleux (Armand), Pachomian Koinonia, vol. I: The Life of Saint Pachomius and his Disciples, Kalamazoo, 1980.

- Vivian (Tim), St. Peter of Alexandria, Bishop and Martyr, Philadelphia, 1988.

- Young (Dwight), Coptic Manuscripts from the White Monastery: Works of Shenoute, Vienna, 1993.

- Youssef (Youhanna), "The Archangel Michael and the Patriarchs in Exile in the Coptic Tradition", in Bosson, N. and Boud'hors, A. (eds.), Actes du huitième congrès international d'études coptes: Paris, 28 juin-3 juillet 2004, Louvain (2007), 646-647. 